研 究

メカニカルアロイングにおける異相界面反応

石原 慶一, ラデンカ・マリチ

近藤 暁裕, 新宮 秀夫

京都大学工学研究科×ネルギー応用工学， 个606-01 京都市左京区吉田本町.

\title{
Formation of Intermetallic Compound by Mechanical Alloying
}

\author{
Keiichi Ishihara, Radenka Marić \\ Akihiro Kondo and Hideo Shingu
}

Department of Energy Science and Engineering, Kyoto University, Yoshida-honmachi Sakyo-ku, Kyoto 606-01.

Received June 10, 1994

Repeated folding and stretching is the process principle of mechanical alloying to produce fine structure. In the case of the system which forms intermetallic compounds, the formation of the intermetallic phase from the lamella structured sample occurres by heating, or, without heating when the lamella spacing is reduced to a critical value. In this study, the relationship between the ignition temperature at which the formation of intermetallic phase start and the lamella spacing was measured for AlCo, AlNi and NiTi systems.

\section{1 緒 言}

メカニカルアロイングは 1980 年ベンジャミン1)が分 散強化型合金の製造に用い,その後アモルファスや他 の合金作成の手段として用いられるょうになり，多く の研究がなされている゙2).

我々はメカニカルアロイングを折り畳みと引き伸ば しの過程であるとみなし,ラメラ構造の栖限として原 子の混合，すなわち合金化と考えて実験を行ってきた 3).しかし,金属間化合物を形成する合金系では綝り返 し区延を行う過程において反応が短時間に起こり，そ の時の層間隔は数十 $\mathrm{nm}$ 程度であることが判明した。 本研究では種々の合金相の反応温度と層間隔の関係を 求めることを目的とした.

\section{2 実験方法}

$\mathrm{Al}, \mathrm{Ni}, \mathrm{Co}$ の金属粉末 (粒径約 $30 \mu \mathrm{m}$ ) を $\mathrm{AlNi}, \mathrm{AlCo}$ の金属化合物組成になるように混合して絽り返し王縮 を行い徽細ラメラ組織を作り，焼鈍し加熱過程での化 合物生成温度を調べた.

また,Ni，Tiの金属箔 (涅さ $10 \mu \mathrm{m}$ ) を多首に交互に 積み重ねそれを圧縮し切断俊皘み重ね圧縮するという 方法により様々な厚さのラメラ組蟣を作った，それを 烍鈍し化合物生成温度を調べた。

金属組織観察は走查型電子頙微鏡, 透過型電子影微 鏡を用いた。 


\section{3 実験結果}

因 1 に $\mathrm{Al}_{50} \mathrm{Ni}_{50}$ をボールミルでメカニカルアロインク を各時間行い, 得られた粉末を固化成形し加熱した時 の試料の温度曲線を示す. 図のようにボールミル時間 が増えるほど発熱ピークの示す金属間化合物形成開始 温度が低下していることが分かる。これはボールミル が進むにつれて組織が細かくなることに起因している と考えられる.

そこで,組織の粗さと反応開始温度を調べるため $\mathrm{AlCo}$, AlNi 各系において混合粉末を絽り返し圧縮を行い, そ の反応開始温度を種々の圧縮回数の試料について測定 した. 図 2 に各王縮回数の組織写真を示す. 図 2-(d)
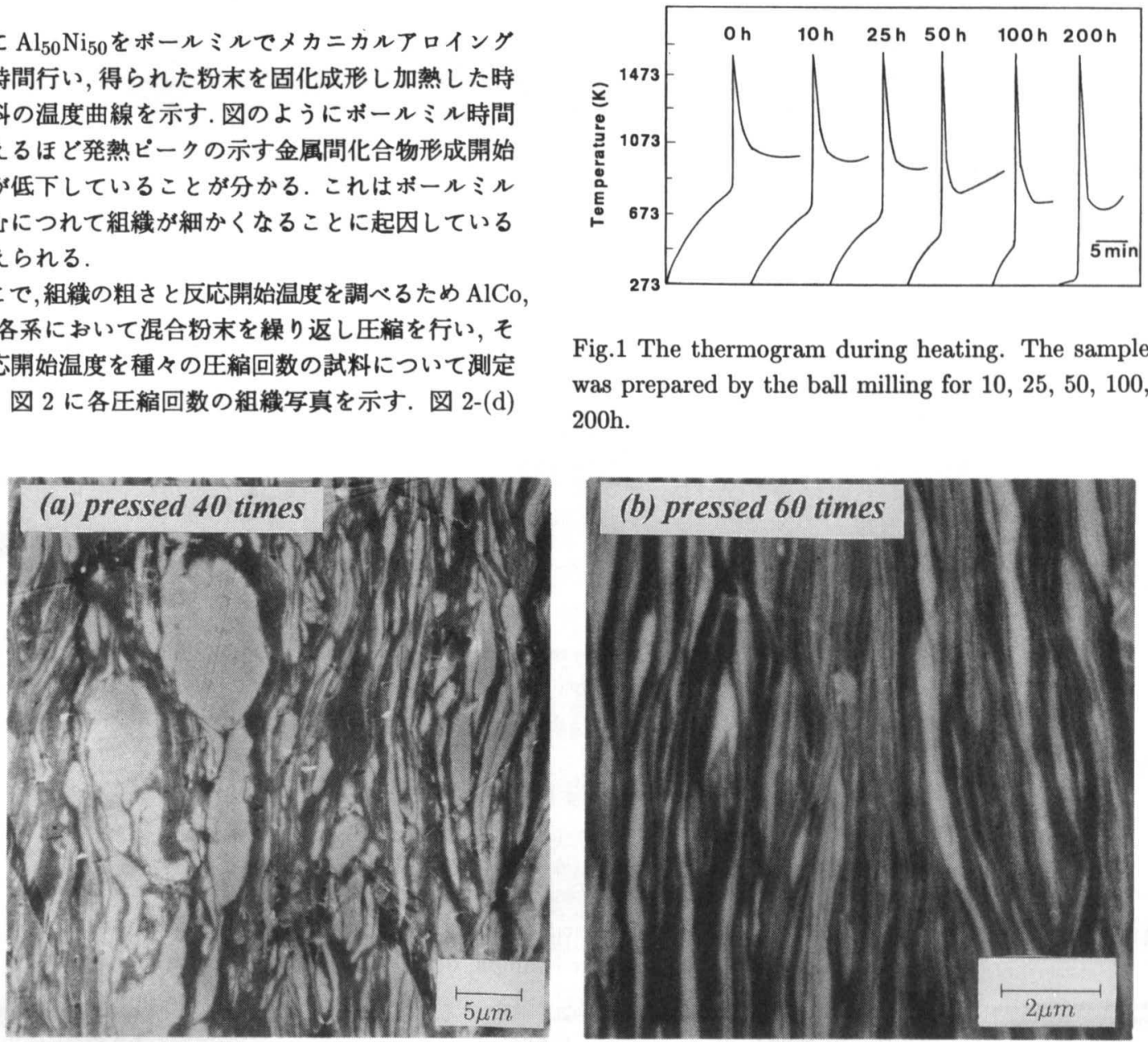

Fig.1 The thermogram during heating. The sample was prepared by the ball milling for 10, 25, 50, 100, $200 \mathrm{~h}$.
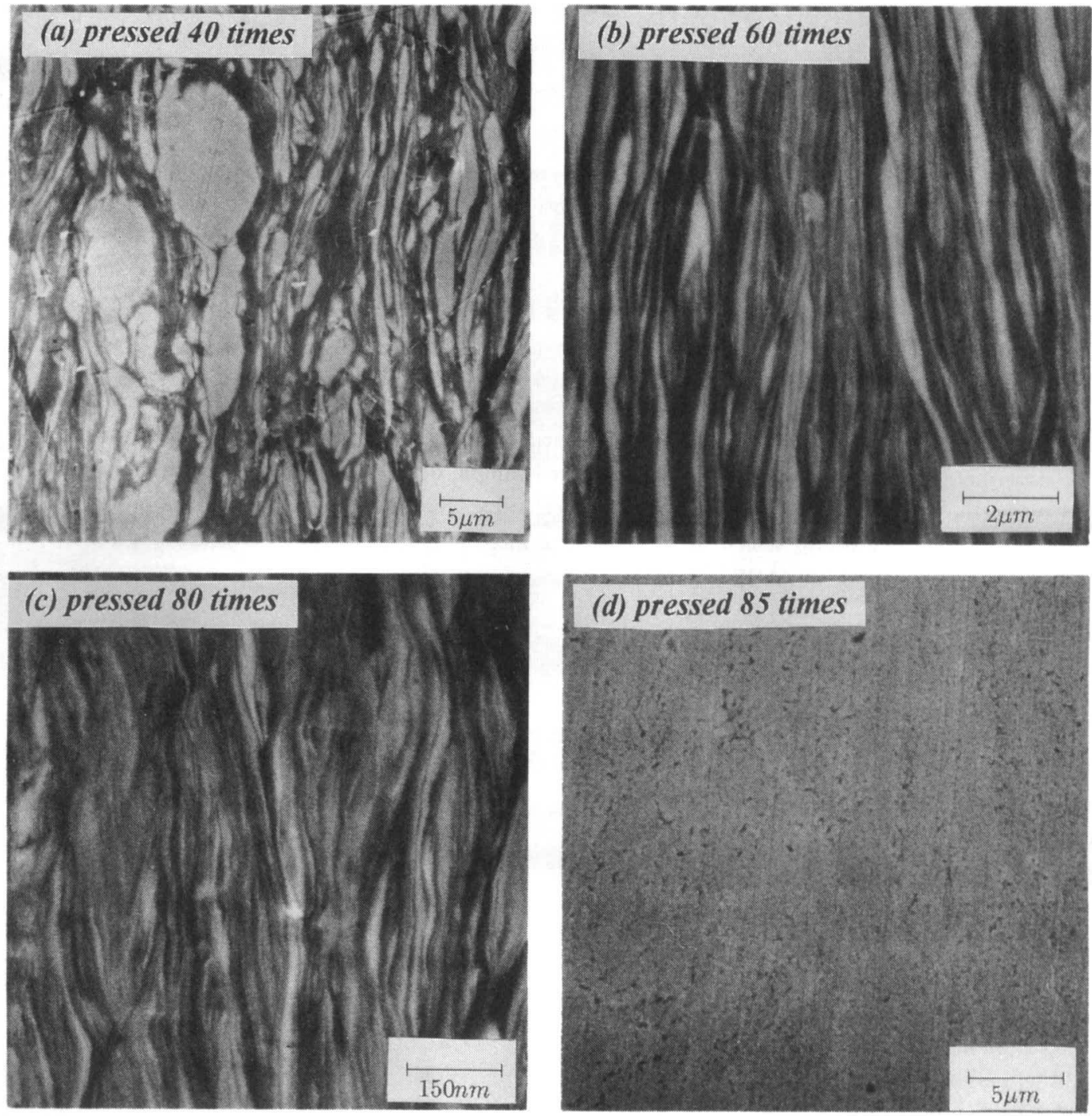

Fig.2 The microstructures of the sample of AlNi after 40,60,80, 85 times pressing. No lamella structure can be observed in the sample after 85 times, because of the formation of intermetallic phase. 


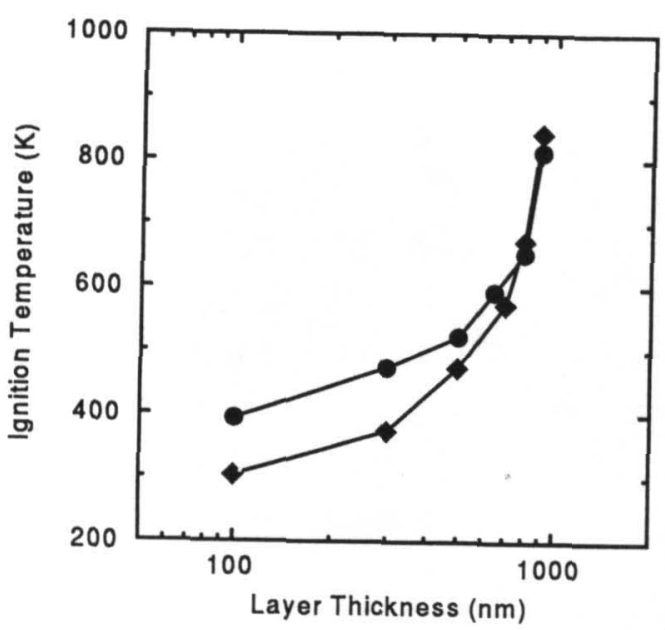

Fig.3 The relationship between the ignition temperature and the layer thickness. and correspond to AlCo and AlNi, respectively.

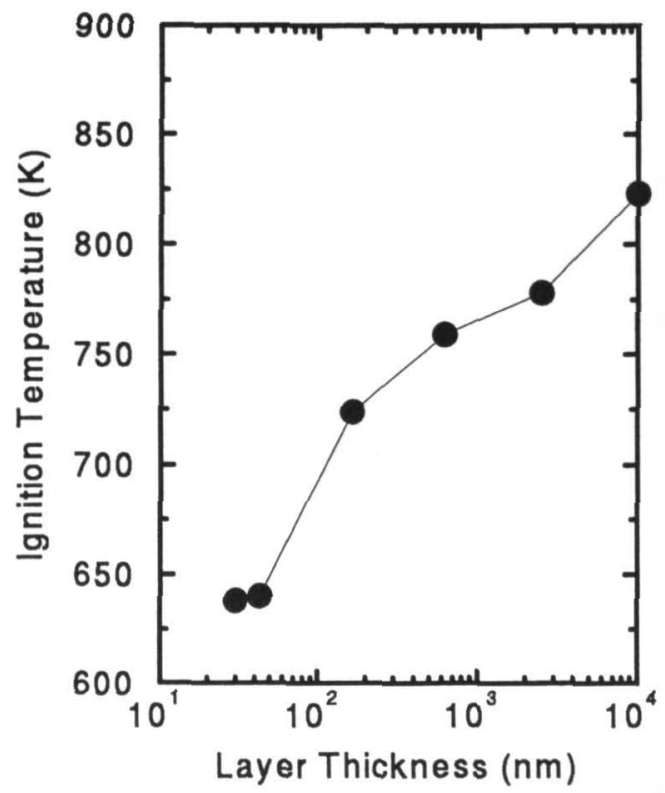

Fig.5 The relationship between the ignition temperature and the layer thickness.

に示されるように圧縮回数が多くなると压縮中に反応 が起こり,実験がそれ以上続けられなかった，図 3 に 層間隔と反応開始温度との関係を示す.

金属粉末ではきれいなラメラがが作成できず組織が 不均一であり, 最も層間隔の小さい所から反応が開始 していると思われる. AlNi, AlCo 系ではそれぞれの
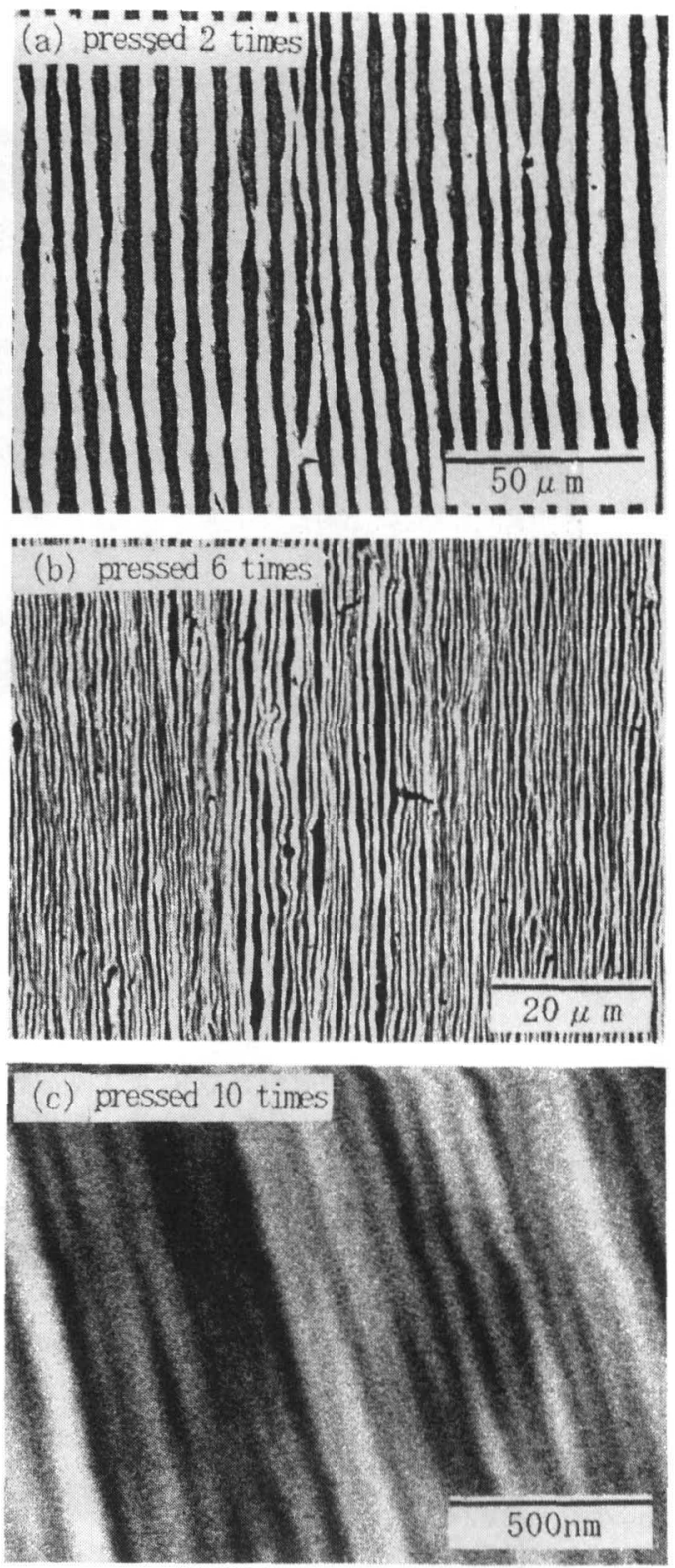

Fig.4 The microstructures of the sample of NiTi after 2, 6, 10 times presseing. Note that more regular lammela structure were observed in comparison with the case of AlNi.

金属単体の塑性変形能が大きく違うため金属箔では実 験ができなかった.さらにこの過程を詳しく調べるた め,NiTi 系において金属箔を交互に積み重ね，それを繰 り返し压縮する実験を行った。この場合も10 回前後 の圧縮で反応が除圧中に起こり, 数十 $\mathrm{nm}$ 以下の層厚 については実験することが出来なかった，モれぞれ所 


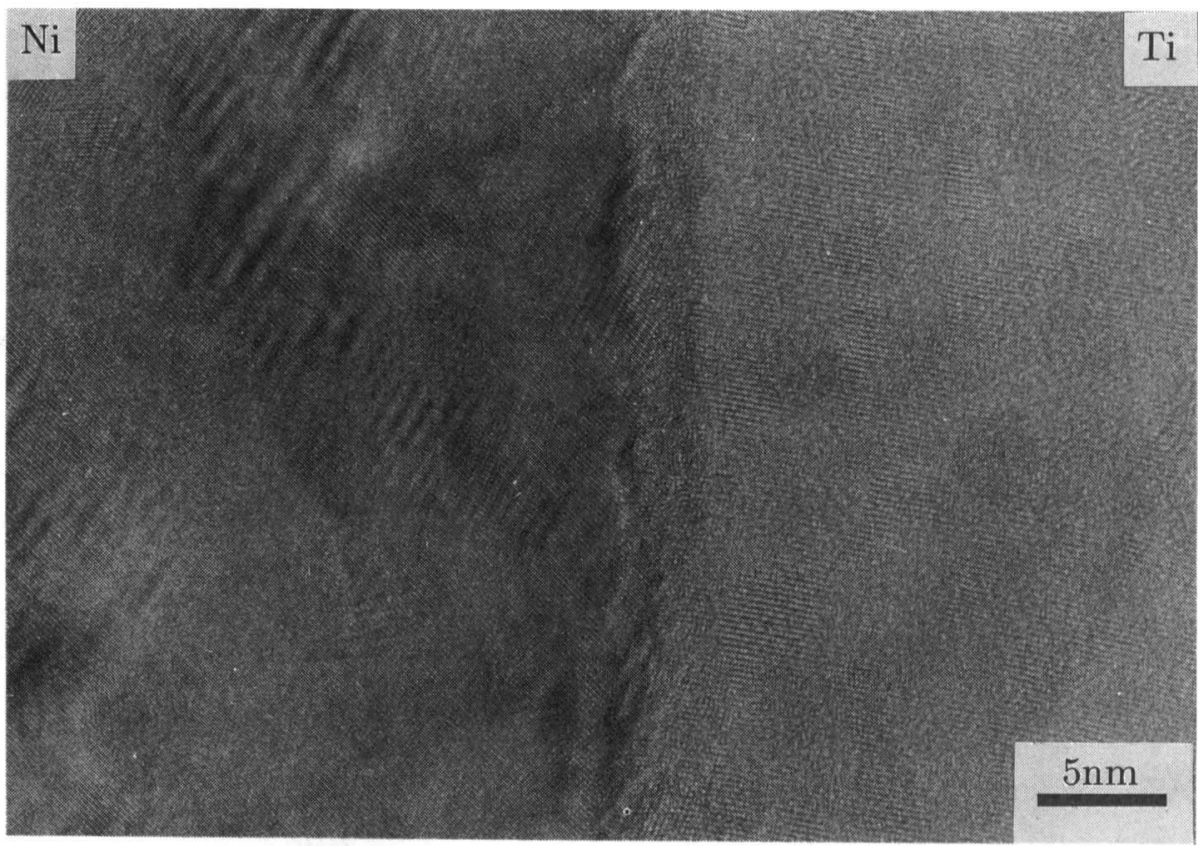

Fig.6 High Resolution TEM photograph for a sample of lamellar thickness of about $1 \mu \mathrm{m}$ produced by the repeated pressing of 15 times starting from the initial $100 \mu \mathrm{m}$ lamellar spacing. In the interface between $\mathrm{Ni}$ and $\mathrm{Ti}$ layer, no intermetallic nor diffusion area was observed.

定回数压縮を綝り返した後の試料をDSC により加熱 し, 金属間化合物への反応開始温度を調べた. 組織変 化を図 4 に, 反応開始温度を図 5 に示す.この場合は 粉末の絽り返し圧縮に比べて遥かにきれいなラメラ組 織を作ることができた. また, $30 \mathrm{~nm}$ 以下になると室温 で压縮中に金属間化合物に反応することがあり, $20 \mathrm{~nm}$ 以下のサンブルを作ることは出来なかった.

\section{4 考察}

いずれの試料においても, 室温において層間隔が数十 $\mathrm{nm}$ になると金属間化合物への反応が起こることが分 かった．もし拡散により反応が起こっているなら室温 で試料厚さが厚いときでも数十 $\mathrm{nm}$ の拡散層が出来て いてもおかしくない，そこで,Ni-Ti系において高分解 能電子顕徽鏡観察を行った. 図 6 に界面の写真を示す. 写真に見られるように拡散層は見られず, また,界面に おける反応層も観察できなかった。このことは単なる 拡散がこの反応を支配しているのではなくある温度, ある層間隔という条件が満たされると界面に核生成が 起こり突然反応が起こる事を示唆している.

ボールミルなどによるメカニカルアロイング中にも 同様の反応が起こり金属間化合物が生成しているもの と思われる. また, このように金属間化合物を形成す ろ系ではメカニカルアロイングで数十 $\mathrm{nm}$ 以下の層間
隔を持った試料を作る事は困難である

\section{5 結 論}

1 各試料とも压縮を繰り返すと,あるとき爆発的に 反応が起こる。

2 ラメラ間隔の減少に伴い化合物生成温度は低下 する。

3 室温における化合物生成臨界層間隔は, $\mathrm{AlNi}, \mathrm{AlCo}$, NiTi それぞれ 100, 80, 50nm であった.

\section{謝辞}

電子顕徽鏡観察に協力していただいた奥建夫博士に感 謝の意を表します。

$$
\text { 文献 }
$$

1) J.S.Benjamin: Met. Trans., 1 (1970) 2943.

2) Materials Science Forum., 88-90.

3) P.H.Shingu, K.N.Isihihara, Y.Yamamoto and K.Yasuna: Ann. Chim. Fr., 18, (1993) 387. 